\title{
PRAWNE ZOBOWIĄZANIA A OBOWIĄZKI MORALNE W FILOZOFII POLITYCZNEJ THOMASA HILLA GREENA
}

Gilozofia polityczna Thomasa Hilla Greena stanowi prosta 1 konsekwencję jego teorii moralnej, więc problem przeciwstawienia prawnych zobowiązań i obowiązków moralnych niemożliwy jest do zrozumienia bez znajomości greenowskiego podejścia do kwestii moralnego rozwoju tak jednostek, jak i ludzkości. Za rozróżnieniem przez niego różnych rodzajów dóbr, do których zmierza w życiu jednostka, idzie rozróżnienie wyższych i niższych rodzajów moralności. Osiąnnięcie pewnego poziomu moralności wskazuje na typ racjonalności, jaką dana jednostka się charakteryzuje. Konkretny typ racjonalności zaś wskazuje, czy jesteśmy jednostkami wolnymi i determinuje sposób podchodzenia do prawodawstwa - świadczy o tym, czy przestrzegamy jedynie prawnych zobowiązań, czy samowolnie nakładamy też na siebie pewne obowiązki moralne. Wszystkie te pojęcia są ze sobą w filozofii Greena ściśle powiązane, nie powinno się więc przechodzić poniekąd ponad greenowską teorią moralności od razu do teorii politycznej, gdyż granica między nimi jest ściśle umowna.

Zacznijmy od stwierdzenia, że Green, za Arystotelesem, powtarza, że jednostka nigdy nie jest atomem egzystującym w próżni, ale zawsze członkiem jakiejś społeczności. Uznaje ją za zoon politikon. Bezpośrednią konsekwencja przyjęcia tego założenia jest stwierdzenie, że swoje cele jednostka może realizować jedynie we wspólnocie i poprzez ta wspólnotę. Jak pisze Green: „życie społeczne jest dla osobowości człowieka tym, czym język jest dla myśli. Język zakłada myśl jako [pewna - J. G.] zdolność, ale w nas zdolność myślenia jest aktualizowana jedynie w języku. W ten sam sposób społeczeństwo zakłada [istnienie pewnejJ. G.] zdolności, podmiotów zdolnych postrzegać siebie i ulepszenie swego życia jako swój cel. Ale jedynie w stosunkach międzyludzkich, w których każdy postrzega innych jako cel, nie zaś jedynie jako środek (...) 
zdolność ta może być realizowana (...)”․ Jak pisze gdzie indziej: „pytać, dlaczego miałbym się podporządkować sile państwa, to pytać dlaczego miałbym pozwolić, by moje życie było regulowane przez kompleks instytucji bez których, literalnie, nie miałbym życia, które mógłbym określić swoim własnym (...). Gdyż nawet jeśli mam życie, które mogę określić swoim własnym, nie moge postrzegać siebie i celów, które sobie przedstawiam jedynie jako moich; muszę mieć możliwość liczenia na określoną wolność działania i posiadania niezbędną dla osiagnięcia tych celów a to może być zabezpieczone jedynie przez powszechne rozpoznanie przez każdego członka społeczności tej wolności jako przynależącej wszystkim członkom społeczności, jako bycia dla powszechnego dobra"2. Społeczeństwo pozwala realizować ideał siebie jako osoby, którą chcielibyśmy być i jaką czujemy, że powinniśmy być. Z tego też względu, realizacja samego siebie, swojego lepszego „ja”, zawsze musi odbywać się we współpracy z innymi. Dla Greena bowiem ideały moralne, które narzucają się nam jako konieczne do realizacji wymagaja rozpoznania i poszanowania przez innych. Jest to niezbędne, gdyż, jak powiedziane zostało powyżej, ich realizacja nie odbywa się w społecznej próżni. Inne jednostki zawsze są w jakiś sposób w tę realizację uwikłane. Właśnie ten społeczny kontekst działalności jednostki i zdanie sobie przez racjonalną jednostkę sprawy z potrzeby współżycia z innymi stanowi warunek sine qua non moralności.

W kwestii greenowskiej teorii moralności należy na początek zauważyć, że projekcje samego siebie w przyszłość, które sa jednym z powodów, dla których Green wprowadza do swojej filozofii pojęcie „wiecznej świadomości”, moga mieć dwojaki charakter. Z jednej strony moga odnosić się do człowieka jako istoty fizycznej, z drugiej zaś jako istoty moralnej. Odpowiednio do tego podziału powstaje rozróżnienie na dobra zwykłe i dobra moralne. Dobra zwykłe zaspokajały będa człowieka jako jednostkę biologiczną, związane będą z odczuciem przyjemności wypływającej z zaspokojenia potrzeb fizycznych, która przemija zaraz po tym zaspokojeniu. W odróżnieniu od nich dobra moralne zaspokajaja człowieka jako istotę moralną, przeważnie nie wiążą się z przyjemnością (a jeśli już to nie przyjemność jest powodem ich realizacji), nie są związane $z$ żadną potrzebą biologiczną i cechuje je „permanentność”. Za tym rozróżnieniem następuje rozróżnienie na moralność „prymitywną" i moralność wyższa. Ideałem Greena jest

1 T. H. Green, Prolegomena to Ethics. With Appendices, Thoemmes Press 1997, s. 192.

2 Tenże, Lectures on the Principles of Political Obligation and Other Writings, Cambridge University Press, Cambridge 1986, s. 90. 
moralność bezinteresowna, to znaczy wypływająca z zatroskania o dobro wspólne nie z powodu własnych partykularnych korzyści, lecz wypływająca z ,inteligentnego patriotyzmu”, z chęci dobrowolnego nakładania na siebie obowiązków w trosce o dobro wspólnoty i współobywateli. Będzie ona skierowana na realizację dóbr moralnych, które u Greena przyjmuja formę dóbr, które można określić mianem społecznych. Rozwojowi tej właśnie moralności powinno sprzyjać państwo. Jest to bowiem, cytując Greena, realizacja pochodu ku „moralnemu końcowi, t.j. uformowaniu społeczeństwa ludzi działajacych z powodu pewnej dyspozycji, z interesu jaki maja w społeczeństwie jako takim” ". Moralność określana przez Greena mianem „prymitywnej” będzie się wiązała się z prostą chęcią osiagnięcia dóbr zwykłych i koniecznością podporządkowania się prawom, które to umożliwiają. Jednostka cechująca się takim poziomem moralności nie będzie świadoma dlaczego prawa wyglądaja tak, nie zaś inaczej i zmierzała jedynie do maksymalnego wykorzystania możliwości, które prawo jej stwarza. Ludzie kierujący się odmiennymi rodzajami moralności będa charakteryzować się różnymi rodzajami (czy raczej poziomami) racjonalności. Racjonalność człowieka jako istoty moralnej będzie się wiązała ze zrozumieniem natury zobowiązań prawnych, których podstawę stanowi podzielana przez współobywateli moralność. Taka jednostka będzie dostrzegała także nieuchronność wzajemnej kooperacji jednostek wypływającej z tego, że dobro własne jest nierozerwalnie związane z dobrem wspólnoty. W swoim rozumowaniu więc będzie stawiała dobro wspólnotowe ze swoim własnym. Racjonalność drugiego rodzaju, którą śmiało możemy określić „instrumentalną”, cechować będzie jednostki, które nie osiagnęły tego „społecznego” poziomu moralności. Będą one traktowały wspólnotę społeczno-polityczna, w której przyszło im żyć, jak „konieczne zło” pozwalające na realizację swoich własnych celów. Skoro zaś w filozofii Greena w zasadzie można postawić znak równości między dobrem moralnym i dobrem społecznym, wówczas jednostki cechujące się rozumnością „instrumentalną” za priorytet swych działań będą stawiać dobra zwykłe.

Zewnętrznie jednostka cechująca się moralności niższą niczym nie będzie się różniła od osoby kierującej się moralności wyższą. Różnica tkwiła będzie raczej w motywach postępowania. Osoba bardziej rozwinięta moralnie będzie rozumiała potrzebę nakładanych na nia obowiązków zachowania zgodnego z literą prawa. Osoba moralna w sposób „prymitywny” będzie tak postępowała z obawy przed karą. Zaś,

3 Tamże, s. 19. 
jak pisze Green, „obywatelstwo to coś więcej niż zwykłe przestrzeganie prawa" ${ }^{4}$. Dlatego właśnie jedno z kluczowych rozróżnień w filozofii politycznej Greena stanowi podział na prawne zobowiązania i obowiązki moralne. Jak pisze sam Green, te pierwsze cechuje:

1. fakt, iż stanowią wyraz państwowego przymusu,

2. obowiązują wszystkich w tym samym stopniu.

W odniesieniu zaś do obowiązków moralnych pisze Green, że cechuje je:

1. fakt, że państwo nie może do nich w żaden sposób przymusić,

2. fakt, że przysługuja jedynie racjonalnym jednostkom jako istotom społecznym,

3. fakt, że tutaj mamy do czynienia z prawdziwym obowiązkiem, z czynami wolnymi i chcianymi, gdyż rozpoznawanymi jako niezbędne dla realizacji tak naszych własnych celów, jak i przyczyniających się do dobrobytu całej wspólnoty.

Obie te kategorie przeciwstawione są $\mathrm{z}$ racji swojej istoty. A. J. Milne pisze, że „moralne obowiązki (...) przynależą osobie racjonalnej jako istnieniu społecznemu. Sa konkretnymi działaniami, które w konkretnych okolicznościach musi wykonywać ona z racji członkostwa w społeczeństwie. Muszą one (...) mieć charakter woluntarny, ponieważ racjonalna jednostka rozpoznaje je jako obowiązkowe w danej sytuacji: w innym przypadku [zachowując się inaczej - J. G.] nie wnosi żadnego wkładu w funkcjonowanie swojego społeczeństwa i nie realizuje siebie jako istoty społecznej. [Wówczas - J. G.] jej działanie nosi znamiona racjonalności, ale [jest to działanie - J. G.] poniżej [odpowiadającego mu - J. G.] poziomu moralnego. Może zachowywać się w sposób zaspokajający go jako prywatną jednostkę, ale nie będzie realizował siebie jako moralnej i, co z tego wynika, społecznej osobowości" ${ }^{5}$. Moralne obowiązki dotycza jednostki jako podmiotu moralnego, prawne zobowiązania zaś koordynują działania jednostek jako istot fizycznych. Dlatego też Green pisze, że „kiedy mówimy o zobowiązaniach jako części ius naturae korelatywnej do praw, muszą być one zawsze rozumiane nie jako moralne obowiązi, nie jako relatywne do stanów woli, lecz jako relatywne do zewnętrznych aktów, których wykonanie lub zaniechanie może i powinno być [przez państwo - J. G.] wspierane".6.

Relacja między instytucjonalnym charakterem społeczności a jej moralnymi zapatrywaniami jest złożona. Istnieje między tymi dwiema kategoriami wzajemna zależność. Moralność ustanawia prawo, prawo zaś

\footnotetext{
${ }^{4}$ A. J. M. Milne, The Social Philosophy of British Idealism, London 1962, s. 126.

5 Tamże, s. 125.

${ }^{6}$ T. H. Green, dz. cyt., s. 17.
} 
jej strzeże. Forma bowiem, jaka prawo przybiera pod postacia ustawy, nie bierze się znikąd. Jak pisze Green, „, (...) państwo, czy raczej suweren jako charakterystyczna dla państwa instytucja, nie tworzy praw, ale daje pełniejszą rzeczywistość prawom już istniejącym. Zabezpiecza i rozszerza wykonanie mocy, które ludzie, determinowani we wzajemnych stosunkach ideą wspólnego dobra, rozpoznali w sobie nawzajem jako bycie zdolnym do kierowania się w stronę tego wspólnego dobra, i które już w pewnym zakresie zabezpieczyli (...)"’7. Prawo, które dziś obowiąuje pod postacią ustawy stanowi tylko werbalizację prawa, które dotąd obowiązywało jako reguła moralna. Z racji tego, że kontrola społeczna jest jednak dużo mniej skuteczna niż prawna, dziś mamy do czynienia z powtórzeniem tych samych zasad na gruncie prawodawstwa.

Współżycie jednostek opiera się zawsze na jakiejś bazie wzajemnie podzielanych przekonań co do tego jak stosunki te powinny przebiegać. Można powiedzieć, że każdy obywatel ma mniej więcej zbliżony z innymi obraz „,reguł gry”, na bazie których w społeczeństwie powinno się działać. Ten ogólny charakter moralności, jako wyraz czynów społecznie faworyzowanych i napiętnowanych określa niekiedy Green mianem woli powszechnej danej społeczności. Zasady moralne w ten sposób społecznie podzielane stanowią pewien wyraz tego, co jednostki uważają za społeczne dobro. Mówiąc inaczej, to, jakie zasady moralne panują $\mathrm{w}$ danej społeczności, wypływa z podzielanej przez obywateli koncepcji dobra powszechnego, którego osiagnięcie powyższe zasady maja umożliwić. Podstawą istniejącego prawa jest zawsze wzajemne rozpoznanie przez obywateli praw które powinny im przysługiwać ze względu na dobro wspólnoty. Sama, „zdolność po stronie jednostki dostrzegania dobra jako jednego dla innych i dla siebie i bycia zdeterminowanym do działania przez tą zdolność, jest podstawa praw; a prawa stanowią niezbędny warunek realizacji tej zdolności"" Oczywiście zasady te, tak, jak związana z nimi forma pożądanej wspólnoty ulegaja przemianom. Świadczy to, zdaniem Greena, o tym, że w kwestii moralności mamy do czynienia z postępem w pewnym określonym kierunku, w kierunku realizacji pewnej formy państwa idealnego (która, jak każdy ideał, jest efektem naszej komunikacji z wieczną świadomością, w której partycypujemy). W państwie demokratycznym instytucje i prawa stanowia odzwierciedlenie woli powszechnej. To właśnie ma na myśli Green, gdy pisze, że suweren nie tworzy praw. Prawa te już istnieją i funkcjonują w społeczności. Teraz

\footnotetext{
7 Tamże, s. 103.

8 Tamże, s. 28.
} 
chodzi jedynie o to, by będąc wyrażonymi w formie aktów ustawodawczych, były zabezpieczone przez państwo przed działaniami antyspołecznymi jednostek, które nie podzielają przekonań większości społeczeństwa. „Nie można powiedzieć - pisze Green - że najbardziej elementarna świadomość prawa jest pierwotniejsza [niż instytucje - J. G.], lub że one są pierwotniejsze w stosunku do niej. One są wyrazem, w którym ta świadomość przyjmuje [formę - J. G.] rzeczywistą"9. Gdzie indziej zauważa, że ,instytucje i prawa odzwierciedlają koncepcję dobra powszechnego; dzięki nim ta koncepcja przybiera formę i staje się rzeczywista; to właśnie dzięki temu, że mają swe miejsce w [świadomości

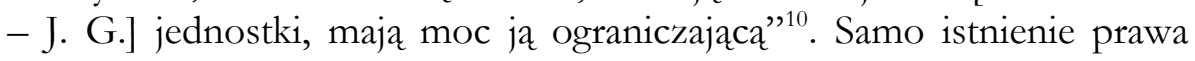
świadczy o tym, że członkowie społeczności uznają jakiś zespół reguł postępowania za słuszny i godny ochrony przed działaniami jednostek aspołecznych. Oczywiście, jako, że wola powszechna cały czas ewoluuje, zmieniać się również muszą instytucje państwowe. W państwie demokratycznym więc prawne zobowiązania są efektem obiektywizacji moralnych dezyderatów podzielanych przez większość społeczności. Skoro tak, to istnieje moralny obowiązek do przestrzegania prawnych zobowiązań, jako że stanowia jedynie dwie strony tej samej monety. Zdaniem Greena, jeśli tylko pozwolimy jednostkom na swobodne wyrażanie swoich przekonań społecznych i politycznych, ten wspomniany wcześniej „pochód ku końcowi” będzie przebiegał w sposób niezakłócony. Ważne, żeby jednostki miały prawo krytyki obowiązujących reguł prawa. W przeciwnym wypadku, żaden rozwój moralny nie będzie możliwy. Przy krytyce „danego systemu prawa, powinniśmy pytać: jak efektywnie przyczynia się do spójnego rozwoju człowieka w tych konkretnych warunkach, w których przyszło mu funkcjonować?"11.

Obowiązki moralne i prawne zobowiązania, jak można zauważyć, mają dwa wspólne elementy:

1. niechęć do pewnych skłonności,

2. świadomość, że ta niechęć oparta jest na rozumie lub koncepcji jakiegoś właściwego dobra.

Zarówno pierwszy, jak i drugi punkt stanowią bezpośrednia konsekwencję rozwoju moralnego jednostki, z jakim zdaniem Green'a mamy do czynienia. Można wyrazić go za pomoca prostego schematu:

\footnotetext{
9 Tamże, s. 91.

10 Tamże.

11 Tamże.
} 
dobro obywatela, dobro rodzica, dobro współplemieńca jako współżycie oparte o zwyczaj, konsensus

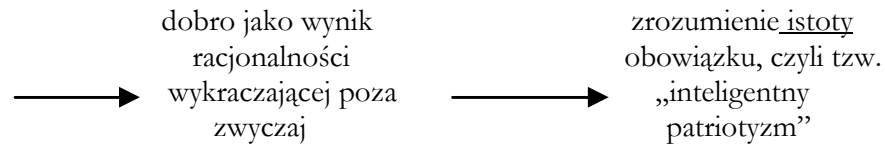

Moralność jako zbiór pewnych reguł postępowania rodzi się na poziomie rodziny. Tutaj więzi są najbliższe, relacje zależności najłatwiejsze do uchwycenia, tu też rodzi się elementarne poczucie odpowiedzialności za inne osoby. Na poziomie społecznym pierwotnie przekonanie o tym, że wspólpraca $z$ innymi jest niezbędna dla realizacji jednostkowych celów, rodzi zwyczaj oparty o konsensus pomiędzy jednostkami. Kolejny „szczebel” rozwoju moralnego, to zrozumienie podstawy tego zwyczaju, zrozumienie relacji łączącej nas $\mathrm{z}$ innymi, dostrzeżenie faktu konieczności wspólnego działania z racji rzeczywistej wspólnoty celów. W końcu ideał moralny - „inteligentny patriota”, który dla dobra wspólnoty rezygnuje z partykularyzmu, w którego świadomości nie ma podziału na interes własny $\mathrm{i}$ wspólnotowy.

W tym, co zostało powiedziane do tej pory, brak jednak odpowiedzi na pytanie dotyczące kwestii obywatelskiego nieposłuszeństwa jako konfliktu moralnego obowiazku i prawnego zobowiązania. Przecież one nie zawsze musza iść w parze. Jak zauważyliśmy, zawsze jako pierwsza ewoluuje moralność, prawodawstwo stara się jedynie za nią podażać. Należy tu rozpatrzyć dwa przypadki. Po pierwsze sytuację, kiedy jednostka podziela poglądy będące wyrazem bardziej rozwiniętej moralności, podczas gdy większość jednostek „nie dorosła" jeszcze do tego poziomu rozwoju moralnego. Drugi przypadek to ten, w którym większość społeczeństwa jest bardziej rozwinięta moralnie, niż by na to wskazywał poziom ustawodawstwa. Jeśli chodzi o pierwsza z tych możliwości, Green odmawia jednostce jakiegokolwiek prawa do łamania powszechnie obowiazujących norm prawnych. Priorytetem zawsze powinno być zachowanie porządku społecznego. Lamanie prawa, a tym bardziej namawianie innych do czynienia tego samego nie może przynieść zmian w świadomości obywateli, a jedynie ta droga może dojść do przekształcenia obowiazującego porządku prawnego. Nieposłuszeństwo może jedynie zachęcić osoby niemoralne do czynienia podobnie. Należy, w miarę możliwości, uznanymi prawnie środkami, skłaniać obywateli do zmiany reguł moralnych, którymi się kieruja. Nawoływanie do nieposłuszeństwa obywatelskiego lub nawet rebelii możliwe jest jedynie w sytuacjach określonych w punkcie drugim - gdy nie ma możliwości zmiany prawodawstwa na drodze 
demokratycznych przemian. Za przykład może tu służyć dyktatura. Green pisze, że ,żadne rozróżnienie nie może być poczynione pomiędzy prawem do życia i prawem do wolności, gdyż nie może być prawa jedynie do życia - nie może być prawa do życia, kiedy nie idzie za nim prawo do kierowania życiem zgodnie z poruszeniami jego woli. Co jest podstawa prawa? Odpowiedź brzmi, zdolność po stronie podmiotu do uczestnictwa w społeczeństwie - do determinacji woli, a przez to i ciała, przez koncepcję dobrobytu jako wspólnego sobie i innym. Ta zdolność jest podstawą prawa lub prawa potencjalnego, które staje się aktualne przez rozpoznanie tej zdolności przez społeczeństwo i przez prawo, które społeczeństwo zastrzega dla jednostki w celu działania zgodnie z tą zdolnością" ${ }^{12}$. Nie można człowiekowi odebrać możliwości współtworzenia wraz z innymi rzeczywistości politycznej, która stanowi zawsze tylko wyraz świadomości społecznej. Gdy tak się dzieje jednostka ma prawo do czynnego oporu. Jednakże nawet w takim przypadku, gdy gwałcone jest prawo jednostki do decydowania o własnym samorozwoju i prawo społeczeństwa do kierowania się w obranym przez siebie celu, wszelkie działania wymierzone przeciwko zastanemu porządkowi prawnemu:

1. nie powinny stanowić jakiegokolwiek zagrożenia dla funkcjonowania państwa jako takiego,

2. powinny się odbywać w oparciu o wolę powszechna, która do tych zmian dojrzała i która pozwala obywatelom odczuć potrzebę przedefiniowania sytuacji ustrojowej.

Wynika to $z$ prostego faktu, że nawet, jeśli gwałcone jest prawo wspólnoty społecznej do samostanowienia, pierwszym obowiązkiem obywatelskim jest zachowanie istnienia wspólnoty.

Ale, pozostając na gruncie dyskusji o zasadach panujących w przypadku państwa rządzonego demokratycznie, zastanówmy się nad tym, jaki charakter powinny mieć prawne zobowiązania, by sprzyjały przyjmowaniu na siebie przez obywateli obowiązków moralnych. Green zauważa, że od faktu przestrzegania prawa do bycia osobą moralna prowadzi daleka i wyboista droga. Jak pisze, ,istnieje moralny obowiązek w odniesieniu do legalnych zobowiazzań, ale nie ma [legalnych - J. G.] zobowiązań w odniesieniu do moralnego obowiązku”" "Obywatelstwo to coś więcej niż przestrzeganie prawa"14. Ma to kluczowe konsekwencje dla funkcji, jakie instytucje państwowe powinny, jego zdaniem,

\footnotetext{
12 Tamże, s. 117-118.

13 Tamże, s. 17.

${ }^{14}$ A. J. M. Milne, dz. cyt., s. 126.
} 
wypełniać. Skoro państwo nie jest w stanie zmienić moralnie jednostki poprzez zmuszenie jej do wykonywania prawnych zobowiązań, to powinno tych starań zaprzestać. Jak zatem sprawić, by jednostki zmierzały do samorealizacji, do moralnego dobra, do dobrowolnego przyjmowania na siebie odpowiedzialności za siebie i za współobywateli? Jednym słowem, jak sprawić, by jednostki zmierzały do bycia lepszymi? Odpowiedź Greena jest jednoznaczna. Trzeba, jeśli chodzi o moralny rozwój, pozostawić je samym sobie. Tak więc, przede wszystkim państwo nie powinno ingerować, nie wykazywać oznak nadopiekuńczości, która może być zgubna w skutkach. Właśnie z powodu tej nadopiekuńczości Green krytykuje idę państwa socjalistycznego, w którym państwo miałoby przejąć kontrolę nad środkami produkcji, by zapewnić wszystkim w miarę równy status materialny. Green twierdzi, że nie tędy droga. Po pierwsze, państwo, nie pozwalając jednostkom na swobodną działalność, uniemożliwia im naukę o samych sobie, o swoich dobrych i słabych stronach, o tym, jak może najlepiej zadbać o siebie i o swoich bliskich. Po drugie, jednostka, której nie pozostawia się możliwości swobodnego działania nie uczy się odpowiedzialności. Jak pisze, „niezbędnym warunkiem, zarówno rozwoju moralności, t.j. pewnego zachowania ludzkiego zdeterminowanego rozumieniem relacji moralnych i wartości jakich nabieraja przez bycie rozumianymi jak i postrzegania tych relacji jako relacji wiazżących wszystkich ludzi jest to, by powinno się pozwolić na wolna grę wszystkich ludzkich możliwości nabywania" ". Będąc zdaną na wieczną opiekę ze strony państwa, jednostka sama nie musi się o nikogo, włącznie z samą soba, martwić. Jeśli zaś tego nie robi, to pozbawia się możliwości zrozumienia:

1. relacji łączących ją $z$ innymi,

2. dostrzeżenia siebie jako części większej całości - społeczeństwa, od której realizacja jej życiowych celów jest zależna,

3. co więcej, jeśli przyjmiemy, że moralność opiera się na bezinteresownym wypełnianiu nałożonych na siebie, przez siebie obowiązków, to zobaczymy, że „rzqd paternalistyczny czyni co może by uczynić to niemożliwym przez zmniejszanie obszaru dla samonakładania obowiązków i na grę bezinteresownych motywów" "16.

Z drugiej strony państwo nie powinno pełnić jedynie roli „nocnego stróża”. Zdaniem Greena na drodze jednostek ku realizacji

15 Tamże, s. 115.

16 Tamże, s. 22. 
lepszego ,ja” czyha wiele niebezpieczeństw. Przede wszystkim grozi im „popadnięcie” w racjonalność ,instrumentalna”. Charakteryzuje się ona dobieraniem środków dla realizacji celu w taki sposób, by zmaksymalizować korzyści podejmując zminimalizowane nakłady. Chodzi o to, że jednostka, która nie będzie pewna swojej przyszłości, lub która będzie skazana na pracę na niewolniczych warunkach (przede wszystkim przy bardzo małych zarobkach) nie będzie nigdy stawiała samorozwoju jako życiowego priorytetu. Zmuszona do ciagłego gromadzenia pieniędzy, skazana będzie jedynie na używanie rozumu w sposób ,instrumentalny”. Będzie powielała, używając analogii z filozofią ucznia Greena, Bernarda Bosanqueta, schemat samorządu, w których termin pierwszy odnoszący się do jednostki stoi w sprzeczności z terminem drugim odnoszącym się do reszty społeczeństwa ${ }^{17}$. Krótko mówiąc, jednostka nie dostrzegając jedności interesów swoich i wspólnoty, będzie postrzegała tę druga jako wroga czyhającego tylko na możliwość jeszcze bardziej dla jednostki dotkliwego jej wykorzystania. Co więcej, dziedziczone będzie ubóstwo, gdyż będzie za nim szedł brak wykształcenia potomstwa uniemożliwiający mu zmianę stanu posiadania. Za kolejny problem społeczny znajdujący się w centrum zainteresowań Greena może posłużyć powszechny w tamtych czasach alkoholizm panujący wśród angielskich robotników zdaniem Greena:

1. uniemożliwiający jakikolwiek rozwój osobowości przez osobę pijąca,

2. mający dalekosiężne konsekwencje dla całej rodziny alkoholika.

Kolejny problem to kwestia niedostępności dla większości społeczeństwa edukacji na poziomi nie tylko ponadpodstawowym, ale i elementarnym. Eliminacja tych zagrożeń za pomoca regulacji prawnych leży w gestii instytucji państwowych. Można u Greena wyróżnić dwa rodzaje funkcji państwowych: negatywne i pozytywne. Funkcje negatywne dotyczą wszystkiego, co związane z zapewnieniem bezpieczeństwa wewnętrznego i zewnętrznego. Jak zauważa A. J. Milne, „jest właściwa funkcja prawa by przymuszać tych, którzy inaczej nie przystosowaliby się do pewnych minimalnych standardów. Są to standardy, które muszą być przestrzegane, jeśli członkowie społeczności maja mieć możliwość osiagnięcia wyższych poziomów racjonalności, do których są zdolni. Te wyższe poziomy muszą być zdobywane w sposób wolny (...) ale prawo może i powinno być użyte do chronienia tych, którzy są zdolni do ich osiągnięcia przed ewentualnością bycia

${ }^{17}$ B. Bosanquet, The Philosophical Theory of the State, Gregg Revivals, Aldershot 1993, s. 50-73. 
„sprowadzonymi” do poziomu mniejszości społecznych, które nie sa zdolne do ciagłego osiagania wyższych poziomów"18. Przymus ma służyć zatem za oręż wymierzony przeciwko tym, którzy nie są zdolni nawet do osiągnięcia najniższego poziomu moralności niezbędnego do świadomej współpracy z innymi na bazie pewnych powszechnie przyjętych norm. W przeciwieństwie do Herberta Spencera (z którym zawzięcie polemizował), Green kładzie nacisk także na pozytywne funkcje agencji rządowych. Państwo musi działać w kierunku zagwarantowania jednostce „prawdziwych możliwości rozwoju” i „podtrzymania warunków życia, w których moralność będzie możliwa" ${ }^{19}$. Czasem interwencja państwowa musi naruszać prawo jednostki do wolnego gospodarowania swoim mieniem, w niektórych za odszkodowaniem może mu być ono nawet odebrane. Green do pozytywnych funkcji państwa zaliczał:

1. regulację godzin i warunków pracy w kopalniach i fabrykach,

2. podniesienie standardów w budownictwie mieszkaniowym,

3. przeciwdziałanie wszelkim naruszeniom standardów jakościowych żywności,

4. publiczny nadzór nad warunkami sanitarnymi, m.in. kanalizacją

5. ustanowienie powszechnego obowiązku podstawowej edukacji,

6. reformę edukacji ponadpodstawowej,

7. reformę uniwersytetów,

8. wyrównywanie różnic społeczno-prawnych między kobietami i mężczyznami; w szczególności zaś zapewnienie kobietom dostępu do edukacji na wszystkich poziomach,

9. zapewnienie dla wszystkich, w szczególności zaś dla pracowników rolnych, możliwości posiadania ziemi,

10. ścisły państwowy nadzór nad handlem alkoholem, włączając możliwość całkowitej prohibicji.

Szczególnie widocznym przykładem, w jaki sposób państwo może przyczynić się do rozwoju moralnego jednostek jest kwestia zapewnienia możliwości posiadania przez wszystkich ziemi. Green zwany bywa niekiedy przez niektórych komentatorów jego filozofii filozofem „trzech akrów i krowy”. Uważał bowiem za zbawienne, zwłaszcza dla dziewiętnastowiecznych robotników, posiadanie niewielkiego pola, które pozwoliłoby przeżyć im i ich rodzinie. Sama świadomość tego, że zawsze jakoś zdołaja wyżywić najbliższych pozwalałaby im wyrwać się, zdaniem Greena, z pułapki racjonalności „instrumentalnej”. Te „trzy akry i

\footnotetext{
18 A. J. M. Milne, dz. cyt., s. 126.

19 T. H. Green, dz. cyt., s. 110.
} 
krowa" pozwoliłyby im również na ewentualną rezygnację z pracy na nieopłacalnych warunkach, co zdaniem Greena wpłynęłoby na zwiększenie płac robotników.

Green wyróżnia jeszcze jedną możliwość przyczyniania się przez instytucje państwowe do moralnego rozwoju jednostek, choć zakres tej możliwości uznaje za ograniczony. Poprzez zabronienie niektórych czynów pod groźbą kary, państwo kreuje intencje obywateli, którzy cechują się niższym poziomem moralności niż ten, którego wyrazem jest wola powszechna. „W powiedzeniu, że właściwa, ponieważ jedyna możliwa, funkcja prawa jest wspieranie wypełniania lub zaniechania pewnych zewnętrznych akcji, tkwi założenie, że jego funkcją jest wytworzenie lub zabezpieczenie przed pewnymi intencjami, gdyż bez intencji nie ma czynu" 20. Właściwym środkiem skutecznie zabezpieczającym przed pojawianiem się pewnych intencji jest, zdaniem Greena, strach przed kara. Możliwość internalizacji przez jednostki reguł obowiązujących w systemie prawnym jest jednak ograniczona jedynie do jednostek nie cechujących się racjonalnością „obywatelską”.

Reasumując: wiele kwestii istotnych z punktu widzenia tytułu powyższego referatu, pozostało przez Greena niesprecyzowanych. Wielu komentatorów jego dzieł wskazuje na fakt mało ścisłego określenia pozytywnych funkcji państwa. Nie podaje on, ich zdaniem, wystarczająco dokładnie zakresu prawnych regulacji, które miałyby się przyczyniać do realizacji przez jednostkę siebie jako istoty moralnej. Zostawia to olbrzymie pole do nadużyć pod pozorem realizacji „prawdziwej racjonalności” i „prawdziwej moralności” jednostek. Jest to uwaga słuszna, choć będąca nieuniknioną konsekwencją samej filozofii Greena, który nie uznawał aprioryzmu prawodawczego. Uważał, że prawa, z racji tego, że mają się przyczyniać do dobra wspólnoty, która zawsze jest jaką́s konkretną wspólnota, w przypadku każdej ze społeczności powinny przyjmować inną formę. Nic dziwnego zatem, że wszelka próba określenia zarówno dziedzin, które powinny być regulowane przez państwo, jak i zakresu, w jakim miałyby być uregulowane, jeśli w ogóle jest możliwa, to przybiera postać bardzo ogólnych zasad niemal zupełnie pozbawionych praktycznego zastosowania. Charakter prawnych zobowiązań musi zawsze bazować na aktualnie podzielanych poglądach obywateli dotyczących dobra wspólnego.

20 Tamże, s. 18-19. 